\title{
Tunesiens udfordringer
}

\section{Rikke Hostrup Haugbølle E \\ Julie Pruzan-Jørgensen}

\section{Den tunesiske befolkning har med stort mod og værdighed væltet deres diktator fra magten; men vejen til et konsolideret demokrati er lang}

Den tunesiske befolkning igangsatte 'det arabiske forår', da de den 14. januar 2011 sendte deres mangeårige diktator Ben Ali i eksil. Men dermed var deres demokratiske transition langt fra sikret. Tuneserne står i dag over for mange og svære udfordringer: Hvordan opbygger man et demokrati i et samfund uden en demokratisk grundlov og uden velfungerende politiske partier? Hvordan skabes der tillid til demokratiske procedurer og aktører efter mange års udhuling? Og, måske allersværest, hvordan skabes der en demokratisk kultur, der giver plads til uenighed og mangfoldighed - og samtidig sikrer politisk og social stabilitet? Dertil kommer de mange og presserende sociale og økonomiske problemer, som oprindeligt udløste det folkelige oprør, og som risikerer at kortslutte den demokratiske proces, hvis de forbliver uløste.

Ben Ali forlod Tunesien den 14. januar. Derefter fulgte to måneder med fortsatte optøjer, idet mange tunesere havde mistillid til de to første midlertidige regeringer, som var dominerede af folk med nær tilknytning til det tidligere regeringsparti, RCD. Først med udnævnelsen den 3. marts af den 85-årige Béji Caïd Essebsi som premierminister for landets tredje midlertidige regering kom der en vis stabilitet tilbage. Efter tre måneder med oprør og demonstrationer trængte tuneserne til hverdag, og mange indså, at Tunesien gik økonomisk i stå, når tiden blev brugt i gaderne frem for på arbejdspladsen. Denne forandring afspejlede sig i de folkelige paroler som ændrede sig fra dégage (skrub af) til engage (engager dig).

Det hjalp også på den folkelige tillid, at der samtidig med Essebsis udnævnelse blev fastlagt et spor for den videre demokratiske transition med annonceringen af en dato for 
valget til en grundlovsgivende forsamling. Denne dato blev oprindelig fastlagt til den 24. juli 2011, men blev efterfølgende udskudt til den 23. oktober samme år på grund af tekniske vanskeligheder med at nå at registrere vælgere og partier samt uddanne observatører.

Valget til den grundlovsgivende forsamling bliver det første af mange i en lang og kompliceret reformproces, idet man i Tunesien (til forskel fra Egypten) har valgt at gennemføre en gennemgribende grundlovsreform. Den grundlovsgivende forsamling skal fremkomme med et forslag til en ny grundlov, som efterfølgende skal vedtages ved en folkeafstemning. Først herefter kan der gennemføres parlamentsvalg - og til slut formentlig også et præsidentvalg. Beslutningen om at gå den lange vej gennem en grundlovsændring giver mulighed for at etablere et helt nyt demokratisk regime, men er samtidig behæftet med store risici og store udfordringer.

\section{Politiske udfordringer}

De fleste tunesere nærer en stor og velbegrundet mistillid til partipolitik og til de 'demokratiske institutioner'. Under Ben Ali sikrede valgsvindel og korruption massive valgsejre til præsidenten og regeringspartiet RCD. Samtidig forekom der en brutal undertrykkelse af den politiske opposition blandt såvel venstrefløjen som islamister, kritiske journali- ster og menneskerettighedsforkæmpere. De mere end 1.000 politiske fanger blev betegnet som almindelige kriminelle, mens de få uafhængige civilsamfundsorganisationer blev mistænkeliggjort og chikaneret.

Udhulingen af de demokratiske institutioners legitimitet parallelt med den brutale undertrykkelse af de fleste alternative politiske aktører betyder, at Tunesien i dag står over for gigantiske politiske udfordringer: Først og fremmest skal der på kort tid opbygges demokratiske institutioner og aktører. I skrivende stund er mere end 90 politiske partier etableret, men kun få har et gennemarbejdet program og en landsdækkende organisation. Også medierne står over for store udfordringer. Fra at være rene propagandamarionetter er de med ét blevet helt frie og skal lære at agere kritisk, ansvarligt og professionelt, ikke mindst hvad angår deres brug af kilder.

I tillæg til de institutionelle udfordringer står tuneserne over for den meget store opgave at skabe en demokratisk kultur, der giver plads til uenighed og mangfoldighed, men som samtidig sikrer et minimum af politisk og social stabilitet. Under Ben Ali tegnedes den politiske opposition primært af på den ene side islamistiske aktivister, som først og fremmest var organiseret i Hizb Annahda (Renæssance Partiet), og på den anden side de sekulære og venstreorienterede menneskerettighedsaktivister. Ikke mindst fælles li- 
delser i fængslerne bragte mange af disse ideologisk uenige aktører nærmere på hinanden i årene op til Ben Alis fald. Efter 14. januar 2011 er sådanne tidligere koalitioner imidlertid blevet opløst.

Dette er en naturlig og nødvendig del af en demokratisk transition, men samtidig har det vist sig ved flere lejligheder, at uenigheden kan vokse til en potentiel fare, når ideologiske forskelle og personlige stridigheder bliver så store og politiserede, at det hindrer en nødvendig konsensus om de overordnede udfordringer og spilleregler (For en uddybende analyse af splittelsen i oppositionen i Tunesien, se Hostrup Haugbølle \& Cavatorta "Will the real Tunisian opposition please stand up?", British Journal of Middle East Studies, forthcoming, 2011).

\section{Den svære mangfoldighed}

\section{Under Ben Ali var der en meget} streng kontrol med dem, der praktiserede islam i dagligdagen. Særligt hårdt ramt var medlemmer af $A n$ nahda, som for en stor dels vedkommende måtte flygte til udlandet for at undgå fængsling. Efter Ben Alis fald er partiets ledere vendt hjem, og partiet er et af de eneste, som har en fungerende organisation, hvorfor det er kommet til at stå relativt stærkt. Partileder Rachid Ghannouchi har gennem et mangeårigt eksil i Storbritannien bevæget sig mod en moderat position. Ghan- nouchi har på forhånd erklæret, at han ikke vil opstille til et fremtidigt præsidentvalg, og at Annahda kun vil opstille kandidater i 30 pct. af valgkredsene ved et fremtidigt parlamentsvalg. Partiet spænder imidlertid over forskelligartede politiske strømninger, og mange sekulært orienterede tunesere er bekymrede for, om Annahda 'taler med to tunger'.

Annahda er langt fra den eneste islamiske aktør, idet en bred vifte af islamiske grupperinger er blevet synlige eller etableret efter Ben Alis fald, bl.a. fem nye partier, der alle inddrager islamiske værdier som en del af deres politiske grundlag.

Den nyvundne ytringsfrihed har endvidere betydet, at diskussionen om islams rolle i Tunesien nu også finder sted bredt i befolkningen. Fordi de islamiske røster i debatten var undertrykt under Ben Alis regime, har den sekulære venstrefløj domineret udlægningen af religionens rolle og plads i Tunesien. For dem var islam nok en del af kulturarven, men religion var en privat sag, som skulle holdes væk fra det offentlige rum og fra politik. Men disse sekulære holdninger udfordres nu af en mangfoldighed af stemmer, idet mange tunesere ønsker, at islam skal spille en bredere rolle i deres daglige liv. Tonen har været så skarp, at enkelte i den sekulære fløj har følt behov for at understrege at de er moderate sekulære.

Det er ikke mindst i forhold til spørgsmål om kvinders rettigheder, 
at bølgerne i debatten om islam går højt. Tunesiske kvinder har i forhold til den øvrige arabiske verden haft en relativt fremtrædende stilling både i familien og i det tunesiske samfund. En af årsagerne hertil var en gennemgribende reform af den sharia-baserede familielov, som blev gennemført af Tunesiens første præsident Bourguiba kort efter uafhængigheden i 1956.

Reformen gjorde blandt andet flerkoneri ulovligt og gjorde skilsmisse til et juridisk anliggende for domstolene. Under Ben Ali gennemførtes en række yderligere tiltag for at fremme kvinders ligestilling inden for blandt andet politik og uddannelse, mens også prævention og abort blev legaliseret.

Ben Ali opretholdt også et dekret udstedt af Bourguiba i 1981, der forbød kvinder at bære slør (hijab) i offentlige bygninger. På trods heraf har stadig flere kvinder gennem det sidste tiår valgt at bære hijab. For nogle af disse kvinder - ligesom for de mænd der har oplevet forbud mod skæg og islamisk klædedragt har det været undertrykkende, at de ikke har haft frihed til at udtrykke deres religiøsitet og at klæde sig efter den. De oplever det som et stort fremskridt, at det efter Ben Alis fald fx er blevet lovligt at bære hijab på det obligatoriske identitetskort.

Over for dem står en lille gruppe stærke, sekulære menneskerettigheds- og kvindeforkæmpere. De frygter, at kvinder i det nye Tunesien vil miste deres rettigheder, fordi der ikke længere er en sekulær stats-feminisme som bolværk mod islamistiske partier og patriarkalske traditioner. Indtil videre har ledelsen af $A n$ nahda bedyret, at den bakker op om kvindens ligestilling og den eksisterende familielov. De har også stemt for paritet på valglisterne til den grundlovsgivende forsamling, således at hver anden opstillede kandidat for alle partier skal være en kvinde. Men mange sekulære kvindeaktivister nærer mistillid til Annahda og andre konservative aktører og frygter, at fremtiden vil føre til en forværring af kvinders stilling i familien og i samfundet.

\section{Sociale udfordringer}

Tunesien står ikke kun over for store politiske udfordringer. Det var store sociale og økonomiske udfordringer, som i sin tid udløste det folkelige oprør, der resulterede i Ben Alis fald, og de kan også spænde ben for den demokratiske transition, hvis de ikke bliver tilstrækkeligt adresseret.

Tunesien fremstod for mange vestlige iagttagere frem til januar 2011 som et arabisk foregangsland på grund af landets store middelklasse og relativt højt uddannede befolkning (UNDP, Human Development Report 2010). Endvidere fremhævedes samfundets sekularisme og kvindernes særstilling og synlighed i det offentlige rum. Endelig blev Tunesien anset som 'Mellemøstens ti- 
ger-økonomi', idet Ben Ali var lykkedes med at gennemføre en række økonomiske reformer, som på én gang tiltrak udenlandske investorer og udvidede jobmarkedet.

Indadtil var virkeligheden dog en ganske anden for den altovervejende del af befolkningen. Særligt ungdomsarbejdsløsheden var et betydeligt problem. I 2008 opnåede kun 20 pct. af de unge ansættelse umiddelbart efter afslutningen af deres uddannelse, og efter 18 mdr. var 67 pct. fortsat arbejdsløse (Verdensbanken, 2008). Et særligt problem var arbejdsløsheden blandt de højtuddannede unge, hvis faglige kvalifikationer ikke modsvarede den økonomiske udvikling, som især var baseret på turisme og på udflytning af europæiske virksomheders lavteknologiske produktion.

Endvidere var landet præget af meget store regionale forskelle i levevilkårene, da særligt landets vestlige og sydlige provinser i mange år er blevet negligeret såvel økonomisk som politisk. Dette afspejledes meget tydeligt i de senere års folkelige oprør, som alle startede langt fra hovedstaden, og som alle i første omgang var baserede på lokalbefolkningens krav om bedre sociale forhold.

Samtidig var økonomien præget af korruption og af præsidentfamiliens private berigelse. En snæver kreds omkring Ben Ali og hans anden kone Leila Trabelsi privatiserede gennem 2000'erne en række statslige selskaber. De kontrollerede blandt andet banker, luftfartsselskaber og hoteller. Både indenlandske og udenlandske investorer måtte invitere familien med som medejere $\mathrm{i}$ nye projekter for at opnå de nødvendige offentlige tilladelser. Tilsammen vurderes det, at Ben Ali- og Trabelsi-familien kontrollerede mellem 40 og 60 pct. af Tunesiens samlede økonomi (Verdensbanken, 2009).

En af de helt store udfordringer er derfor nu at få gennemført grundlæggende forandringer i den økonomiske kultur, herunder at etablere transparente forretningsgange og merit-baserede ansættelser. Hertil kommer et stort arbejde med at kortlægge og omfordele de mange rigdomme, som Ben Ali- og Trabelsifamilien havde konfiskeret. Samtidig er overgangsregeringen meget begrænset af sit midlertidige mandat. Den har således hverken bemyndigelse til at indgå forpligtende internationale aftaler, for eksempel om en ny, fordelagtig landbrugsaftale med EU, eller til at gennemføre presserende reformer på arbejdsmarkedet.

Oven i disse problemer er den $\varnothing$ konomiske udvikling blevet sat voldsomt tilbage efter revolutionen. Nedgangen har været mest markant i arbejdskraftintense sektorer med mange ufaglærte såsom minedrift, tekstil og (især) turisme (Economist Intelligence Unit, London, April 2011). Dette er baggrunden for 
mange unge tuneseres ønske om at komme til Europa, herunder de seneste måneders unge tunesiske bådflygtninge ved Lampedusa. De flygter, fordi revolutionen ikke har bragt dem jobs, men tværtimod på kort sigt har gjort deres jobudsigter endnu ringere.

I tillæg hertil er den tunesiske økonomi også hårdt ramt af krisen i Libyen, som udgjorde et helt centralt marked, ikke mindst på grund af den store uformelle import af varer fra Libyen. Kampene i Libyen har betydet, at denne samhandel er gået mærkbart ned, ligesom den tunesiske turistindustri er blevet yderligere ramt af den usikre og urolige situation i nabolandet. Samtidig har mere end 400.000 flygtninge fra Libyen lagt store ekstraudgifter på den i forvejen hårdt trængte tunesiske økonomi.

Endelig har der også været en markant stigning i antallet af strejker efter Ben Alis fald. Ganske forståeligt har mange forskellige befolkningsgrupper benyttet sig af deres nye frihed til at udtrykke deres utilfredshed og kræve bedre vilkår. Også her står overgangsregeringen over for en stor udfordring, idet den på den ene side må vise forståelse for befolkningens krav og frustrationer - men samtidig skal sikre at $\varnothing \mathrm{ko}-$ nomien kommer i gang igen, og at udenlandske investorer igen får tillid til den tunesiske økonomi.

Ud over de store politiske, sociale og økonomiske udfordringer udgør den fortsatte usikkerhed og mistillid endnu en trussel mod den demokratiske transition. Ikke bare antallet af strejker er steget siden den 14. januar. Politiske demonstrationer er fortsat også hyppigt forekommende, især i Tunis og i de vestlige regioner. Mens de fleste forløber fredeligt, har der flere gange været voldelige sammenstød mellem politi og demonstranter. I april 2011 blev to skoleelever således dræbt og 43 såret i provinsbyen Kesserine.

Også andre former for voldelige lokale opgør finder sted. I den sydlige provinsby Metlaoui (tæt på grænsen til Algeriet) var der i juni 2011 særdeles voldelige opgør mellem to forskellige stammer - noget man ikke har set i mange år i Tunesien, hvor tilhørsforhold til stammer og klaner har været et tabubelagt og overset emne. Årsagen til konflikten i Metlaoui var rygter om, at en lokal fosfatfabrik foretrak en stamme frem for en anden i sine ansættelser. Mere end 140 tunesere blev anholdt efter optøjerne - heriblandt tidligere RCD-folk. Mange tunesere er bange for, at tidligere RCD-folk spøger i kulissen og arbejder på at destabilisere ikke bare Metlaoui, men hele landet for igen at kunne overtage kontrollen.

Ildspåsættelse af fængsler og undslupne kriminelle fanger er faktorer, der bidrager til destabilisering af sikkerheden i landet og skaber mistro til de politiske aktører. Det er uklart, hvordan det flere gange er lykkedes 
fanger i forskellige fængsler at gennemføre ildspåsættelser og flygte under evakueringerne. Dette kombineret med at det fra overgangsregeringens side flere gange har lydt, at "der er kræfter på spil, som ikke ønsker sikkerhed og ro i Tunesien”, har åbnet for spørgsmål om, hvorvidt overgangsregeringen har en interesse $\mathrm{i}$ at skabe en sådan frygt for at legitimere sig selv.

Samtidig er der kun få myndigheder til at opretholde ro og orden. Det tunesiske politi tabte stor troværdighed på grund af dets rolle $\mathrm{i}$ nedkæmpelsen af demonstranter i ugerne op til den 14. januar. Mange betjente sagde efterfølgende op eller blev afskedigede. Den manglende politi-tilstedeværelse er for mange en daglig påmindelse om, at sikkerheden i landet endnu ikke er intakt. Værre er det imidlertid, at der fortsat berettes om, at politiet begår vold, tortur og umotiverede arrestationer af demonstranter. Endvidere fortæller journalister og menneskerettighedsforkæmpere, at de igen overvåges, $o g$ at der sker hemmelige ransagelser af deres huse.

Rygtedannelse, mistillid og usikkerhed er alle forhold, som i høj grad udfordrer den demokratiske transition. Skal den lykkes, kræver det at den midlertidige regering hurtigt gennemfører et stop for alle ulovlige overgreb på demonstranter og kritiske stemmer samt, at de efterfølgende valgte politisk ledere gennemfører gennemgribende re- former af både politi og retsvæsen samt foretager et retsopgør med fortidens syndere. Kun på den måde vil de kunne sikre sig befolkningens fortsatte tillid og opbakning til de mange svære politiske valg og prioriteringer, de har foran sig.

\section{Udfordringer og potentiale}

Den tunesiske befolkning indledte 'det arabiske forår' - og har udvist enestående mod og værdighed. Den har nu begivet sig ind på lang, grundig og kompliceret demokratisk reformvej, som kan føre tuneserne mod det første, konsoliderede demokrati i den arabiske verden. Men processen er skrøbelig, og udfordringerne mange og komplicerede.

Selvom det tunesiske folk har vist stor vilje og kompetence, vil de i de kommende år have brug for international støtte i arbejdet med at konsolidere deres demokratiske transition. Mange vestlige aktører (herunder EU) svigtede i mange år den tunesiske befolkning ved at se igennem fingrene med den politiske undertrykkelse under Ben Ali. De har nu mulighed for at råde bod ved at bidrage til den demokratiske konsolidering.

Rikke Hostrup Haugbølle er ph.d. stipendiat ved Institut for Tverkulturelle og Regionale studier, Københavns Universitet. Julie Pruzan-Jørgensen er ph.d. og projektforsker ved Dansk Institut for Internationale Studier (DIIS). 